\title{
FEATURES OF QUANTITATIVE MEASUREMENTS OF THE DYNAMIC MODULE OF ELASTICITY OF BINDERS IN OPTIMIZATION OF PRODUCTION TECHNOLOGY SEROGYPSUM COMPOSITE
}

\author{
${ }^{1}$ Tarasevych V.I., PhD., Assistant Professor, \\ vittars@ukr.net, ORCID: 0000-0002-3249-7029 \\ ${ }^{1}$ Gasan Yu.G., PhD, Professor, \\ gasan.iug@knuba.edu.ua, ORCID: 0000-0002-3249-7029 \\ ${ }^{1}$ Kyiv National University of Construction and Architecture \\ Vozdukhoflotsky Avenu 31, Kyiv, 03680, Ukraine \\ ${ }^{2}$ Dolgoshey V.B., PhD., Assistant Professor, \\ vdolgoshey@ukr.net, ORCID: 0000-0002-0147-3534 \\ ${ }^{2}$ NTUU "KPI named after Igor Sikorsky" \\ Peremohy Avenu 37, Kyiv, 03056, Ukraine
}

\begin{abstract}
The paper considers the issues of studying the structure formation of binders during hardening to determine the optimal moments of mechanical action on gypsum concrete specimens, which makes it possible to optimize the technology of their impregnation with sulfur melt. The time dependence of the elastic modulus of a hardening, binder is its important physicochemical characteristic, since it is used to objectively identify the stages of structure formation, to simulate the processes occurring at each of the stages. It is noted that the method of acoustic resonance of bending vibrations, in the case of hardening binders, needs correction with respect to the measurement technique and interpretation of the results obtained. The kinetics of the resonance frequency of a sample consisting of a rigid cell and a dispersion poured into it is a function of the elastic properties of the cell, the dispersion itself, the contact zone of the dispersion with cell and therefore cannot be used for either qualitative or quantitative analysis of the kinetics of hardening. Taking into account the elasticity of cuvette is necessary to obtain reliable information.

It has been established that in the presence of shrinkage or significant expansion of the binder, the study of structure formation by the resonance method should be carried out in plastic cuvettes. Regardless of shrinkage, the use of a cuvette requires compulsory consideration of its elastic properties. It is advisable to objectively distinguish the stages of structure formation on the basis of the kinetics of not the dynamic modulus of elasticity itself, but the rate of its change. The time dependence of the logarithmic damping decrement is also an important characteristic of the concrete structure. The studies carried out make it possible to obtain serogypsum composites with the necessary performance characteristics and to manufacture elements of architectural décor, wall fencing products of increased aesthetics, durability and reliability from them.
\end{abstract}

Keywords: gypsum, sulfur, sulfur melt, resonance method, elastic modulus.

Formulation of the problem. It is known that sulfur is a typical inorganic thermoplastic which is capable of forming numerous allotropic modifications, and at the same time, in the molten state, it has a low viscosity. Sulfur is well compatible with various polymer modifiers. By introducing various additives, it is possible to adjust the viscosity and surface tension over a wide range. Sulfur has strong adhesive bonds to mineral fillers and aggregates. Under normal conditions it is chemically inert and, even when heated, is practically insoluble in water and acids. Sulfur is diamagnetic, a poor conductor of heat, has insecticidal properties, and is hydrophobic. It has a low melting point, which allows it to be converted from a solid to a liquid state at low energy consumption [1]. From a technological point of view, the process of crystallization of a sulfur melt upon cooling is simpler than the polymerization of monomers in the manufacture of concrete polymers.

It follows from the above that sulfur, as an impregnating material, has many valuable properties and can be used for impregnation of various building capillary-porous materials, in

Bulletin of Odessa State Academy of Civil Engineering and Architecture, 2021, no. 83, page 86-92 
particular, gypsum concrete.

Analysis of recent research and publications. Currently, there are several technological methods for obtaining building materials and products using sulfur of various modifications. One of them is the impregnation of traditional building materials and products with molten sulfur, the other is the production of sulfur concrete. The well-known property of sulfur melt to form strong adhesive bonds with various mineral fillers makes it possible to use sulfur as a basis for a sulfur binder mastic, which, in turn, is the basis of the structure of sulfur concrete [2-4]. One of the most valuable properties of sulfur-based composite materials is their high corrosion resistance. In a number of works, it is noted that sulfur concrete is resistant to the effects of various acids. However, these works did not investigate issues related to physicochemical phenomena occurring during the interaction of a gypsum or gypsum matrix and sulfur, and the processes of drying and impregnation were not sufficiently considered from the point of view of their optimization. The peculiarities of the capillary-porous structure of gypsum concrete and their behavior at elevated temperatures require the development of scientifically substantiated technological modes of drying and impregnation with sulfur melt [5-7].

The aim of the work is to study the influence of different types of cells on the measurements of the dynamic elastic modulus of binders during hardening to determine the optimal moments of mechanical action on gypsum concrete specimens, which will optimize the technology of their impregnation with molten sulfur.

Materials and research methods. To study the kinetics of the resonance frequency, the dispersion was poured into a thin-walled cuvette measuring $150 \times 15 \times 5 \mathrm{~mm}$, in the region of the nodes of the standing wave of which the wire leads of the exciter and the oscillation receiver were located. Oscillations were excited using a piezoelectric head and a low frequency generator. The amplitude of the forced vibrations of the sample was recorded with a piezoelectric detector, amplifier, and voltmeter. In the manual mode, the resonant frequency was recorded by a frequency meter, provided that the maximum amplitude of forced oscillations was reached. In the semiautomatic mode, the resonance peak contour was recorded automatically when the generator frequency was manually changed due to the connection of the generator and amplifier with a computer. In this case, the resonant frequency and the logarithmic damping decrement were determined automatically. The accuracy of determining the resonant frequency is $0.2 \%$ with a logarithmic damping decrement of 0.01 .

Research results. The time dependence of the modulus of elasticity of a hardening binder is its important physicochemical characteristic, because it is used to objectively distinguish the stages of structure formation, to simulate the processes occurring at each stage, and also to determine the optimal moments of mechanical action on concrete. Such dependence is most often evaluated by acoustic methods, however, the method of acoustic resonance of bending vibrations, developed in relation to systems with parameters that are stable in time, but in the case of hardening binders, needs to be corrected relative to the measurement technique and interpretation of the results obtained [8-11].

This primarily refers to the frequency of the resonance peak $f$, since the resonant frequency of the sample is the derivative of the elastic properties of both the binder and the cuvette itself. For solidified dispersions, the contribution of the cuvette elasticity is relatively small and the distortions introduced by it may be insignificant. In the case of plastic dispersions, the elasticity of even a minimally rigid cell is much higher than the elastic properties of the binder, and the resonance frequency $f$ of the sample is a complex function of the elasticity of the cell, the zone of contact of the dispersion with the cuvette, and the dispersion itself $G$. Just after mixing, the elastic properties of the dispersion are negligible, therefore, its resonant frequency cannot exceed $50 \ldots 60 \mathrm{~Hz}$. In the experiment, with a cuvette length of $150 \mathrm{~mm}$ and a sample mass of $25 \mathrm{~g}$, an $f$ value of about $500 \mathrm{~Hz}$ is fixed, which is due to the exclusively elastic properties of the cuvette and the sample mass. Thus, the value of $\mathrm{G}$ cannot be calculated only on the basis of the measured values of the resonance frequency of the sample, its geometric and mass characteristics.

It was shown in [8] that the elasticity of the cell can be taken into account within the framework of the model of two coupled vibrational subsystems (the binder and the cell). The

Bulletin of Odessa State Academy of Civil Engineering and Architecture, 2021, no. 83, page 86-92 
resonance frequency $f_{d}$ of the solution part of the sample calculated on the basis of this model corresponds to the value of $G$; therefore, the kinetics of the frequency $f_{d}$ rather than $f$ is a more adequate characteristic of structure-forming processes. From the time dependence of the resonance frequency of the solution part of the sample $f_{d}$, the modulus $G$ can be determined. Fig. 1 shows the kinetics of the frequencies $f$ and $f_{d}$ of the sample of the aqueous dispersion of $\beta$-hemihydrate gypsum. As expected, the kinetics of the frequency $f_{d}$ starts from values close to zero, but not from $570 \mathrm{~Hz}$, like the frequency $f$.

Investigation of the peculiarities of the kinetics of the frequency $f$ made it possible to establish [10] that until the moment of time $t_{0}$ (the point of transition from the initial horizontal section to the ascending branch) a continuous crystallization framework in the dispersion does not yet exist. In the main section of structure formation (ascending branch of the graph), the increase in elasticity is due to the processes of creating and reinforcement of crystallization contacts. The parameter $t_{0}$ corresponding to the moment of creation in the dispersion of a continuous structure with crystallization-type contacts, objectively characterizes the start of setting and the upper limit for the time of non-destructive mechanical action on the dispersion.

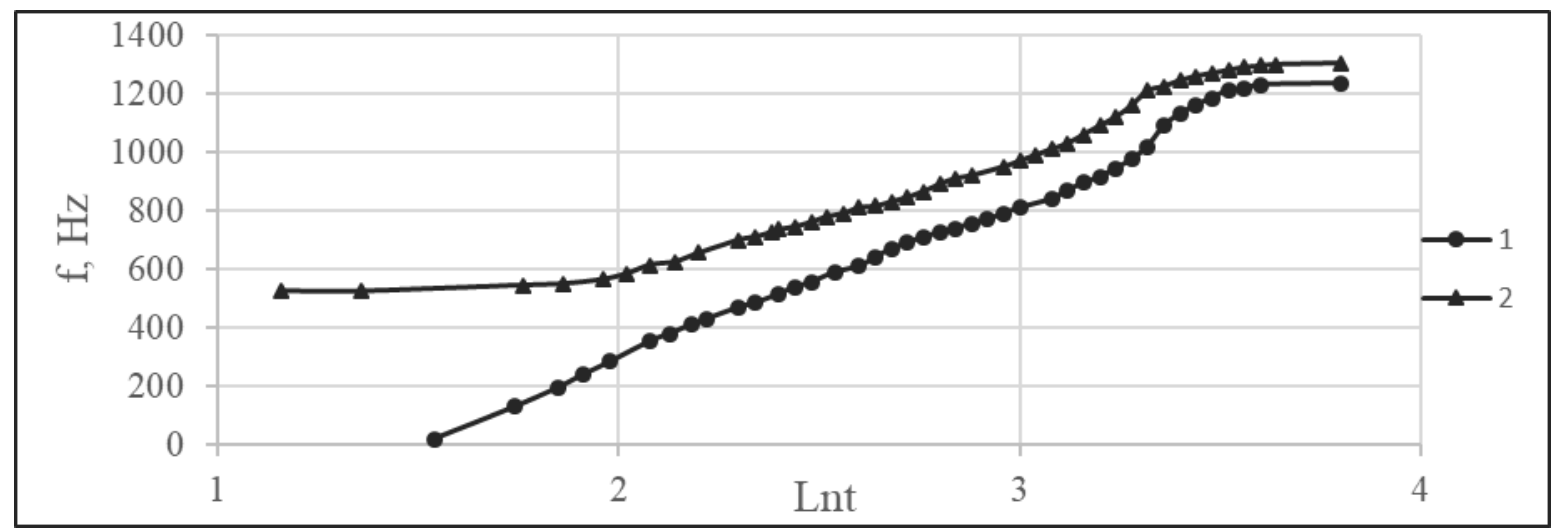

Fig. 1. Kinetics of the resonant frequency of an aqueous dispersion of hemi-aqueous gypsum in a metal cuvette:

1 - resonance frequency of a system consisting of a cuvette and dispersion (experimental data); 2 - resonance frequency of the solution part of the sample (calculation according to the data of curve 1)

The second factor affecting the measured kinetics of frequency $f$ is the character of the coupling of the cuvette with dispersion [11]. Since the sample is an example of two coupled vibrational subsystems, it is necessary that the elastic nature of their connection persists over time. This means that the cuvette must change its dimensions simultaneously with the dispersion. If the cuvette is rigid, then during shrinkage or significant expansion, the dispersion is partially detached from the walls, the condition of coupling of the vibrational subsystems is violated. In the presence of shrinkage at the beginning of hydration, due to the connection of a sufficiently rigid cell with a still fragile binder stone, its structure is decayed (macrocracks appear) and distortions are introduced into the kinetics of $f$, which are of fundamental importance for the interpretation of the results.

The study of the influence of the cuvette on the nature of the kinetics of the resonance frequency was carried out using examples of aqueous dispersions of Portland cement grade M400 from the Zdolbunovsky plant and kaolinite. Measurements in rigid cuvettes showed that within 40 ... $180 \mathrm{~min}$. from the beginning of mixing in the case of Portland cement, a well-known from the literature [8,9] S-shaped section on the kinetics of frequency $f$ is fixed (curve 1 in Fig. 2). The behavior of the logarithmic damping decrement (LDS) is also oscillating in this region, and its maximum corresponds to the minimum of $f$. It was also found that the beginning of the frequency decrease coincides with the beginning of the formation of cracks in the dispersion and its detachment from the walls of the cell.

A similar correlated behavior of the damping frequency and the process of macroscopic destruction of the structure of the sample has a unwanted influence of cuvette on the kinetics of the

Bulletin of Odessa State Academy of Civil Engineering and Architecture, 2021, no. 83, page 86-92 
resonance frequency. The decrease in frequency during hardening is not due to the syneresis phenomenon in the formed colloidal structure, but is due to macroscopic violation of the integrity of both the dispersion itself and the zone of its contact with the cell surface. In this case, the destruction of the macrostructure is not due to the inherent shrinkage of the dispersion, the obstacle from the side of the cuvette to the free shrinkage of the binder.

To eliminate partial destruction of the sample, the dispersion should be poured into a cuvette made of plastic material. When shrinking dispersion in such a cuvette, there are no cracks and detachments. The kinetics of the frequency $f$ of the portland cement dispersion in the plastic cuvette is presented in Fig. 2.

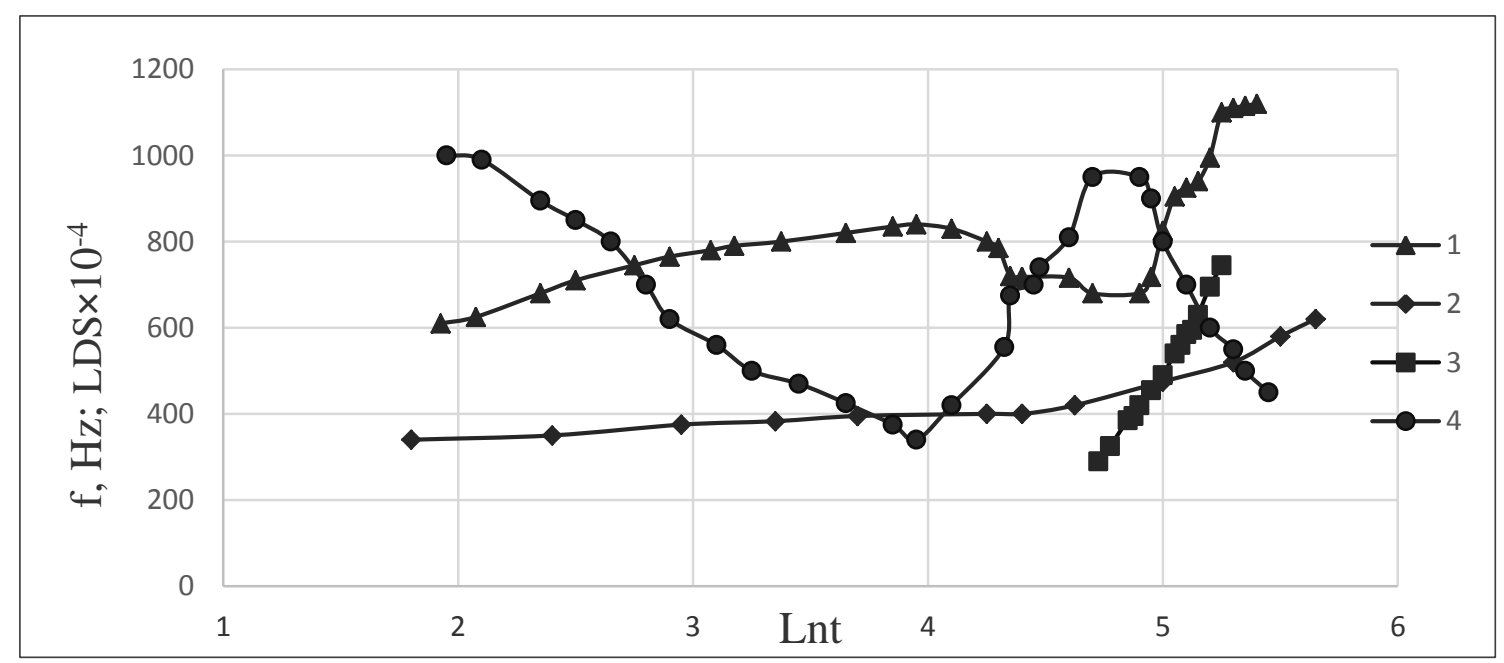

Fig. 2. Dependence of the resonance frequency of a cement paste sample in a metal cuvette (1), a plastic cuvette (2), without a cuvette (3) and the logarithmic damping decrement of the sample in a metal cuvette (4) on time ( $t$ in minutes)

As follows from the figure, there is no $S$-shaped section on the dependence $f=F(\mathrm{t})$, and the value of LDS decreases monotonically without take-offs. This indicates that the processes of partial destruction of the sample macrostructure does not occur. We obtained similar results for the dispersion of kaolinite, where the destruction processes were not observed in the plastic cell, the resonance frequency increased monotonically, the damping decreased, while in the metal cell, due to shrinkage, the dispersion cracked and almost completely exfoliated from the walls, the frequency $f$ after the previous growth rapidly decreased, the value of LDS increased at the same time to values of $0.2 \ldots 0.3$.

Distortions due to plastic cuvettes were also controlled by examining dispersion samples freed from the cuvette. In this case, the dispersion was poured into a mold, which was subsequently disassembled and the beams were measured in pure form. For gypsum, it was found (see Fig. 1) that the model of two coupled vibrational subsystems makes it possible to obtain data similar to the results of measurements of cuvetteless samples. Therefore, for gypsum stone, the correct frequency kinetics can be obtained by mathematical treatment of the measurement results in a rigid cuvette.

In the case of a cement paste, the study of a cuvetteless beam is possible from the points in time corresponding to the end of the $\mathrm{S}$-shaped section (curve 3 in Fig. 2). The data obtained show a satisfactory coincidence of the kinetics of the resonance frequency of the beams and the dispersion samples in a plastic cuvette.

Thus, the kinetics of the resonance frequency of a sample consisting of a traditionally rigid cuvette and a dispersion poured into it is a function of the elastic properties of the cuvette, the dispersion itself, the contact zone of the dispersion with the cuvette and therefore cannot be used for either qualitative or quantitative analysis of the kinetics of hardening. Even in the absence of dispersion shrinkage, taking into account the elasticity of the cuvette is necessary to obtain reliable 
information. If, in the course of hardening, a significant deformation of dissolved part of the sample occurs, then it is necessary to use plastic cuvettes.

The use of the resonance frequency $f_{d}$ of the dissolved part of the sample makes it possible to determine not only the kinetics of the dynamic modulus of elasticity $G$, but also the rate of its change $V=\mathrm{d} G / \mathrm{d} t$. The $V$ value characterizes the hardening rate, therefore, it provides important information about the special points of the kinetics of the elastic modulus and, therefore, allows us to objectively identify the stages of structure formation. Figure 3 shows the dependence of the $V$ value of the aqueous dispersion of gypsum binder on time. From Fig. 1 and Fig. 3, it follows that on the kinetics of the rate value of $V$, the individual stages of hardening are marked out much more clearly than in the kinetics of the resonance frequency.

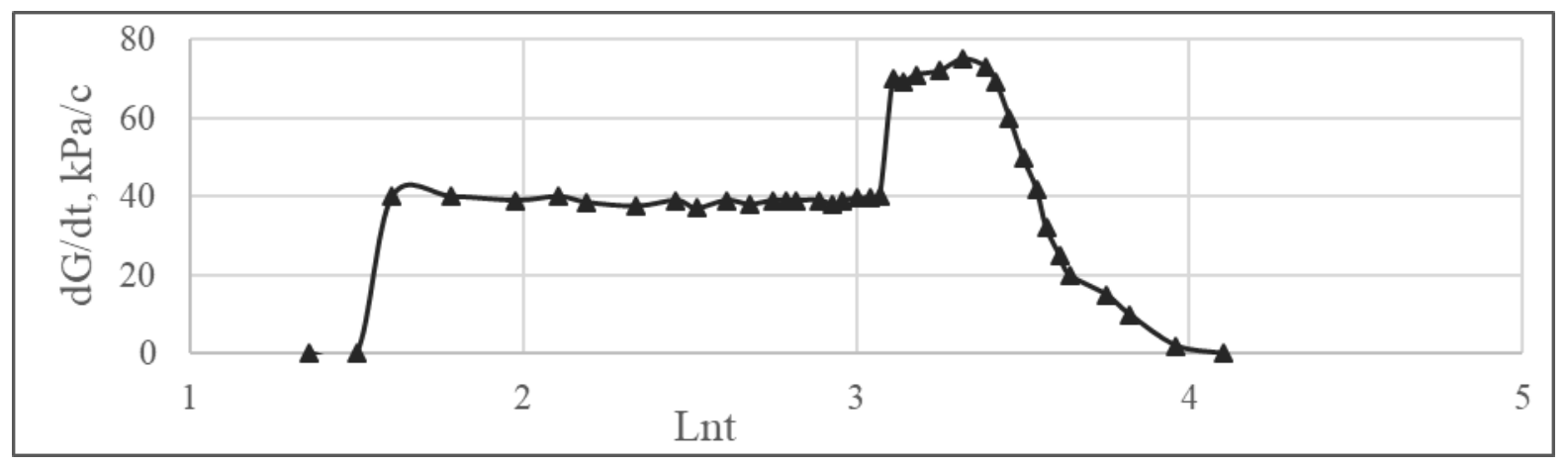

Fig. 3. Dependence of the rate of change of the dynamic modulus of elasticity of an aqueous dispersion of semi-aqueous gypsum on time ( $t$ in minutes)

An important dispersion characteristic is also the LDS, which is determined by the width of the resonance peak at half its height. Our studies have shown that during the hardening of the dispersion, the value of LDS, monotonically decreased, can experience temporary bursts. In this situation, a temporary increase in the damping decrement indicates a partial macroscopic destruction of the sample. With an increase in the half-width of the peak, its amplitude significantly decreases; therefore, the use of the kinetics of the peak amplitude without knowledge the behavior of its half-width and the shape of the amplitude-frequency characteristic of the setup does not seem correct.

Conclusions. Based on the studies carried out, it was found that in the presence of shrinkage or significant expansion of the binder, the study of structure formation by the resonance method should be carried out in plastic cuvettes. Regardless of shrinkage, the use of a cuvette requires compulsory consideration of its elastic properties. It is advisable to objectively distinguish the stages of structure formation on the basis of the kinetics of not the dynamic modulus of elasticity itself, but the rate of its change $\mathrm{V}$. The time dependence of the logarithmic damping decrement is also an important characteristic of the structure of concrete. The studies carried out make it possible to obtain serogypsum composites with the necessary performance characteristics and to manufacture elements of architectural décor, wall fencing and facing products of increased aesthetics, durability and reliability from them.

\section{References}

[1] M.A. Menkovsky, V.T. Yavorsky, Sulfur technology. M.: Chemestry, 1985.

[2] V.V. Paturoev, A.N. Volgushev, Yu.I. Orlovsky, "Sulfur concrete and concrete impregnated with sulfur", Survey. Inform. Construction Materials. M.: VNIIIS Gosstroy of the USSR, ser. 7, vol. 1, pp. 1-60, 1985.

[3] Yu.M. Bazhenov, V.S. Demyanova, V.I. Kalashnikov. Modified high quality concrete. M.: ASV, 2006.

[4] L.I. Dvorkin, O.L. Dvorkin, Special concrete. M.: Infa-Engineering, 2012.

[5] Yu.G. Gasan, V.I. Tarasevych, V.B. Dolgoshey, "Investigation of the toxicological safety

Bulletin of Odessa State Academy of Civil Engineering and Architecture, 2021, no. 83, page 86-92 
of the production and operation of products made of serogypsum composite", Keramika. Science and Life, no. 2(43), pp. 15-17, 2019.

[6] Yu.G. Gasan, V.I. Tarasevych, O.V. Drozdova, "Special facing building material based on gypsum modified with ash and sulfur", Naukovi notatki, no. 63, pp. 56-61, 2018.

[7] Yu.G. Gasan, V.I. Tarasevych, G.V. Kucherova, O.V. Sergienko, "Modification and study of composite materials based on gypsum binder with high ash content of thermal power plants", Bulletin of the Odessa State Academy of Civil Engineering and Architecture, no.57, pp. 53-57, 2015.

[8] I.G. Granovsky, Structuring in mineral binders, Kyiv: Nauk. Dumka, 1984.

[9] Yu.S. Sarkisov, "Kinetic aspects of the processes of structure formation of dispersion systems", Announcing of Universities. Construction, no. 1, pp. 38-42, 1994.

[10] V.A. Klimenko, V.I. Klapchenko, V.I Tarasevych, S.I. Stepanenko, "Formation of elastic structures in aqueous and alcohol-aqueous suspensions of semi-aqueous gypsum", Depon. In the State Scientific and Technical Library of Ukraine 15.09.95 №938, Ukraine, 1995.

[11] V.A. Klimenko, V.I Klapchenko, "The effect of shrinkage on the parameters of elastic vibrations of samples of hardening systems", Depon. In the State Scientific and Technical Library of Ukraine 18.06.96 №1445, Ukraine, 1996.

\title{
ОСОБЛИВОСТІ КІЛЬКІСНИХ ВИМІРЮВАНЬ ДИНАМІЧНОГО МОДУЛЯ ПРУЖНОСТІ В'ЯЖУЧИХ В ОПТИМІЗАЦІЇ ТЕХНОЛОГІЇ ОТРИМАННЯ СЕРОГІПСОВОГО КОМПОЗИТУ
}

\author{
${ }^{1}$ Тарасевич B.I., к.т.н., доцент, \\ vittars@ukr.net, ORCID: 0000-0002-3249-7029 \\ ${ }^{1}$ Гасан Ю.Г., к.Т.Н., професор, \\ gasan.iug@knuba.edu.ua, ORCID: 0000-0002-2510-4418 \\ ${ }^{1}$ Київський національний університет будівництва і архітектури \\ Повітрофлотський проспект 31, Київ, 03680, Україна \\ ${ }^{2}$ Долгошей В.Б., к.ф.-м.н., доцент, \\ vdolgoshey@ukr.net, ORCID: 0000-0002-0147-3534 \\ ${ }^{2}$ Національний технічний університет "Київький політехнічний \\ інститут “ імені Ігоря Сікорського \\ проспект Перемоги, 37, Київ, 03056, Україна
}

Анотація. В роботі розглянуті питання дослідження структуроутворення в’яжучих в процесі тверднення для визначення оптимальних моментів механічної дії на гіпсобетонні зразки, що дозволяє оптимізувати технологію їх просочування розплавом сірки. Часова залежність модуля пружності твердіючого в'яжучого $є$ його важливою фізико-хімічною характеристикою, оскільки вона використовується для об'єктивного виділення етапів структуроутворення, моделювання процесів, що протікають на кожному з етапів. Відмічається, що метод акустичного резонансу, у випадку твердіючих в'яжучих, потребує корекції відносно методики вимірювань та трактовки отриманих результатів. Кінетика резонансної частоти зразка, що складається з жорсткої кювети і залитої в неї дисперсії, $є$ функцією пружних властивостей кювети, самої дисперсії, зони контакту дисперсії з кюветою і тому не може бути використана ні для якісного, ні для кількісного аналізу кінетики твердіння. Врахування пружності кювети $є$ необхідним для отримання достовірної інформації.

Встановлено, що при наявності усадки або значного розширення в'яжучого, дослідження структуроутворення резонансним методом повинно проводитися в пластичних кюветах. Не залежно від усадки використання кювети вимагає обов'язкового врахування їі пружних властивостей. Об'єктивне виділення етапів структуроутворення доцільно проводити на основі кінетики не самого динамічного модуля пружності, швидкості його зміни. Часова залежність логарифмічного декременту згасання також $є$ важливою 
характеристикою структури бетону. Проведені дослідження дозволяють отримувати серогіпсові композити з необхідними експлуатаційними характеристиками і виготовляти 3 них елементи архітектурного декору, стінові огороджувальні і облицювальні вироби підвищеної естетичності, довговічності і надійності.

Ключові слова: гіпс, сірка, розплав сірки, резонансний метод, модуль пружності.

\title{
ОСОБЕННОСТИ КОЛИЧЕСТВЕННЫХ ИЗМЕРЕНИЙ ДИНАМИЧЕСКОГО МОДУЛЯ УПРУГОСТИ ВЯЖУЩИХ В ОПТИМИЗАЦИИ ТЕХНОЛОГИИ ПОЛУЧЕНИЯ СЕРОГИПСОВОГО КОМПОЗИТА
}

\author{
${ }^{1}$ Тарасевич В.И., к.т.н., доцент, \\ vittars@ukr.net, ORCID: 0000-0002-3249-7029 \\ ${ }^{1}$ Гасан Ю.Г., к.т.Н., профессор, \\ gasan.iug@knuba.edu.ua, ORCID: 0000-0002-2510-4418 \\ ${ }^{1}$ Киевский национальный университет строительства и архитектуры \\ Воздухофлотский проспект,31, Киев, 03680, Украина \\ 2 Долгошей В.Б., к.ф.-м.н., доцент, \\ vdolgoshey@ukr.net, ORCID: 0000-0002-0147-3534 \\ ${ }^{2}$ Национальный технический университет "Киевский политехнический \\ институт " имени Игоря Сикорского \\ проспект Перемоги, 37, Киев, 03056, Украина
}

\begin{abstract}
Аннотация. В работе рассмотрены вопросы исследования структурообразования вяжущих в процессе твердения для определения оптимальных моментов механического воздействия на гипсобетонные образцы, что позволяет оптимизировать технологию их пропитки расплавом серы. Временная зависимость модуля упругости твердеющего вяжущего является его важной физико-химической характеристикой, поскольку она используется для объективного выделения этапов структурообразования, моделирования процессов, протекающих на каждом из этапов. Отмечается, что метод акустического резонанса изгибных колебаний, в случае твердеющих вяжущих материалов, нуждается в коррекции относительно методики измерения и трактовки полученных результатов. Кинетика резонансной частоты образца, состоящего из жесткой кюветы и залитой в нее дисперсии, является функцией упругих свойств кюветы, самой дисперсии, зоны контакта дисперсии с кюветой и поэтому не может быть использована ни для качественного, ни для количественного анализа кинетики твердения. Учет упругости кюветы является необходимым для получения достоверной информации.

Установлено, что при наличии усадки или значительного расширения вяжущего исследование структурообразования резонансным методом должно производиться в пластичных кюветах. Вне зависимости от усадки использование кюветы требует обязательного учета ее упругих свойств. Объективное выделение этапов структурообразования целесообразно производить на основе кинетики не самого динамического модуля упругости, а скорости его изменения. Временная зависимость логарифмического декремента затухания также является важной характеристикой структуры бетона. Проведенные исследования позволяют получать серогипсовые композиты с необходимыми эксплуатационными характеристиками и изготавливать из них элементы архитектурного декора, стеновые ограждающие и облицовочные изделия повышенной эстетичности, долговечности и надежности.
\end{abstract}

Ключевые слова: гипс, сера, расплав серы, резонансный метод, модуль упругости. 